\title{
Groundwater Pollution Risk Assessment Based on Vulnerability to Pollution and Potential Impact of Land Use Forms
}

\author{
Robert Duda*, Iwona Klebert, Robert Zdechlik \\ AGH University of Science and Technology, Faculty of Geology, Geophysics and Environmental Protection, \\ Krakow, Poland
}

Received: 29 September 2018

Accepted: 12 February 2019

\begin{abstract}
Our research aimed to evaluate groundwater pollution risk in the study area in southeastern Poland, that is, in an area where the hydrogeological conditions and land use forms are similar to those of European plains. The authors' own qualitative classifications of the potential impact of major forms of land use on groundwater quality and groundwater pollution risk are proposed. The degree of this risk was assessed as the sum of ratings of intrinsic vulnerability of groundwater to pollution assessed with the original DRASTIC method and ratings of the potential impact of land use. The obtained map of groundwater pollution risk showed that $0.3 \%$ of the study area was characterized as being at very high risk, $50 \%$ as high, $45 \%$ as moderate, and $4.7 \%$ as low. In a graphical manner, spatial relationships between selected factors affecting the groundwater pollution risk and the assessed degree of risk are presented. The assessment of groundwater pollution risk employing intrinsic vulnerability of groundwater to pollution and potential impact of land use forms, together with the proposed classification of groundwater pollution risk, made it possible to determine areas of high risk of groundwater pollution in the study area in an effective manner.
\end{abstract}

Keywords: groundwater pollution risk, risk assessment, risk classification, intrinsic vulnerability, land use

\section{Introduction}

Groundwater constitutes a natural source of fresh water, mainly used for consumption and communal purposes. Groundwater pollution risk is mainly related to hydrogeological factors, that is, vulnerability of groundwater to pollution and anthropogenic factors

*e-mail:duda@agh.edu.pl related to the land use forms, as described by [1-6], among others. When the areas of high groundwater pollution risk are indicated, appropriate preventative measures can be undertaken, as indicated for example by $[7,8]$.

Risk can be defined as the probability of an unwanted event that results in negative consequences, as stated by [9], among others. High probability, that is, high risk of contamination, can be achieved only when a highly vulnerable area has a high probability of exposure to contamination [10]. Moreover, it has been indicated that 
the probability should be quantitatively determined as a percentage of from 0 to $100 \%$ [10]. However, reliable quantitative determination of groundwater pollution risk is difficult as it depends on many factors, some of the mhardly measurable, and thus assessments of groundwater pollution risk are usually qualitative instead quantitative. Some groundwater pollution risk assessments focus on the risk stemming from only one specific source of pollution, for example nitrates derived from agricultural fertilization [11-19], waste disposal sites [20, 21], or even biofuel-related land use [22].

Aiming at a final, reliable groundwater pollution risk assessment, researchers often focus on the result of the uncertainty evaluation of this risk assessment.

Locally measured nitrate concentrations are usually taken as an indicator of current degradation of groundwater quality, such as in [11-19]. In this way, a purely theoretical possibility of occurrence of an unwanted event is linked with real facts. The approach to reducing the degree of uncertainty of groundwater pollution risk assessment is usually done by validation of data and factors affecting this risk. As a result of validation, researchers modify the primarily accepted original method of assessment of intrinsic vulnerability of groundwater to pollution, usually by changing the weights of selected factors or by introducing additional factors or parameters affecting this risk, such as in [11-19]. In this way, (i) there is an intentional or unintentional shift from the assessment of intrinsic vulnerability to a specific one, (ii) the result obtained by the modified method of groundwater pollution risk assessment becomes closer to the observations of the current concentrations of specific compounds, usually nitrates, but as a result it is an assessment of groundwater-pollution-specific risk instead of an assessment of the overall risk of groundwater pollution arising from any potential factor.
When analysing the risk in large areas, it is difficult to assess the impact of all potential points or local sources, which are of importance only on a local scale. Usually, aggregation of these sources into groups is used. Nevertheless, in areas with smaller surfaces, groundwater pollution risk assessments are performed, including detailed separation of many types of potential anthropogenic sources of groundwater pollution. A detailed list of many such sources of pollution together with the proposal of relevant weights of potential harmful impacts on groundwater quality is given by [1], among others.

The presented research aimed at a qualitative assessment of groundwater pollution risk employing the intrinsic vulnerability of groundwater to pollution and potential impact of land use forms in the study area. To perform this risk assessment, the authors' own qualitative classifications of the potential impact of major forms of land use on groundwater quality and groundwater pollution risk have been proposed. With the aim of increasing the universality of the adopted approach and classifications, the study concerns the assessment of the overall risk of pollution and not risk specifically related to selected compounds, such as nitrates, and the study area selected was one where hydrogeological conditions and land use forms are typical of European plains. Another objective was the presentation and analysis of the spatial relationships between the obtained result of the groundwater pollution risk assessment and the main factors taken into account in this risk assessment.

\section{Materials and Methods}

\section{Study Area}

The study area of $443.5 \mathrm{~km}^{2}$ is located in southeastern Poland and constitutes the northwestern fragment of

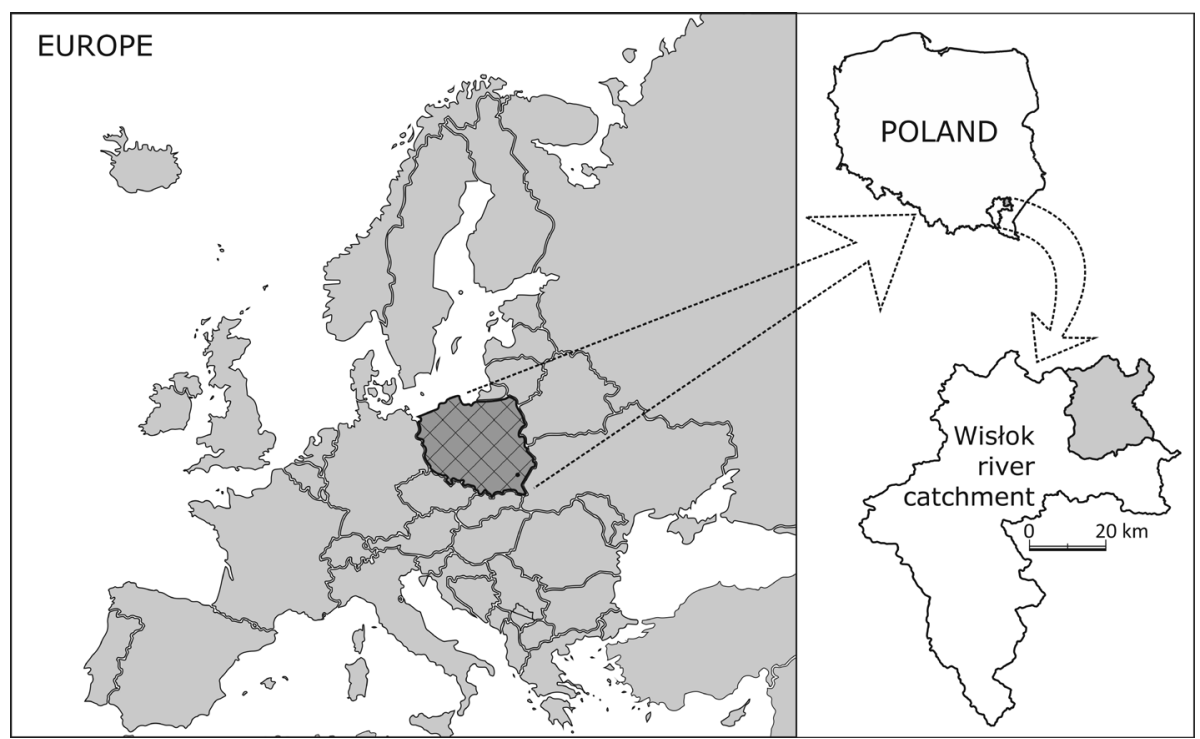

Fig. 1. Location of research area. 

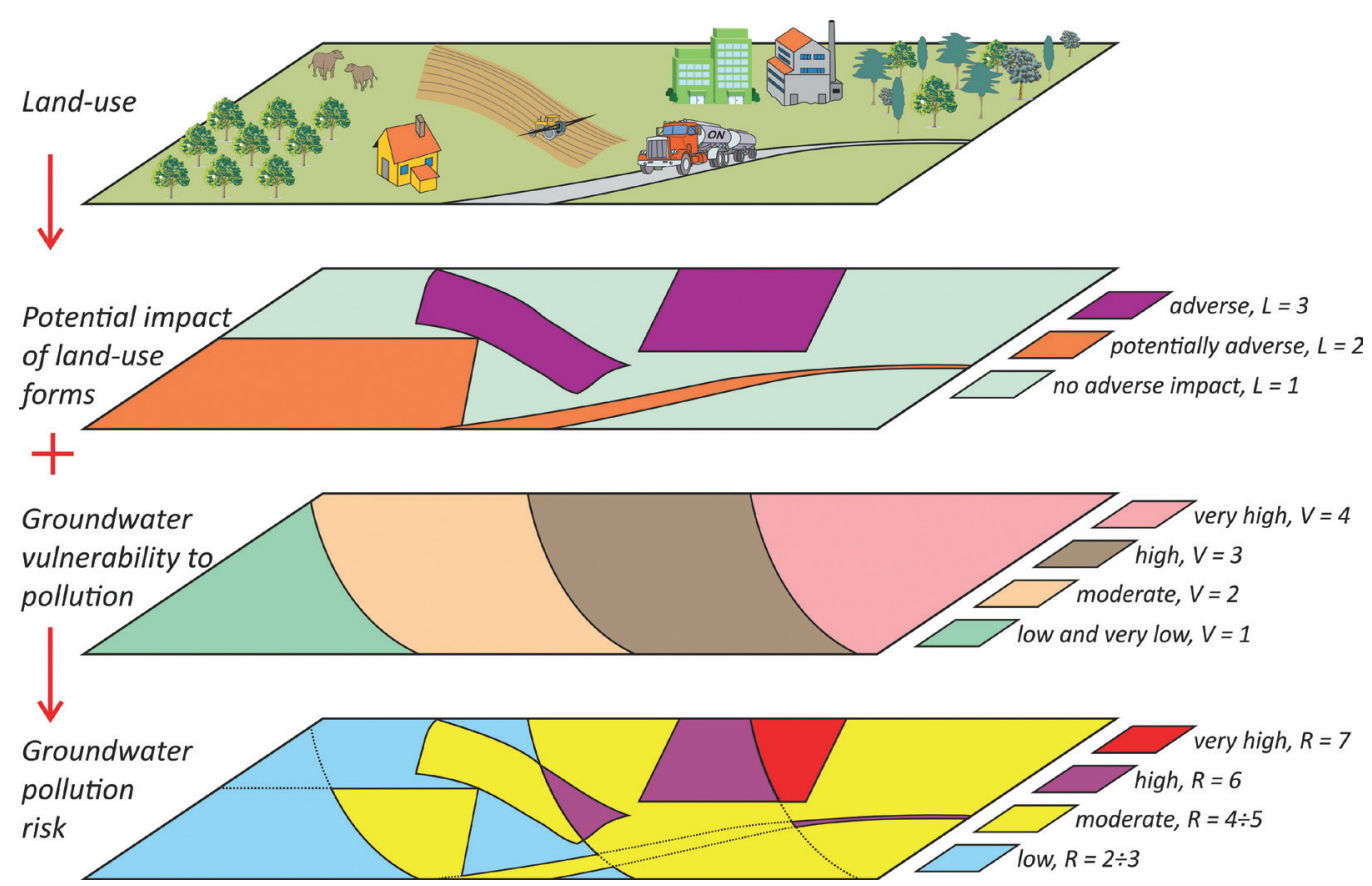

Fig. 2. Conceptual model of groundwater pollution risk assessment accepted in this study. Ratings of $\mathrm{L}$ and $\mathrm{V}$ factors in accordance with Table 1; rating of risk (R) in accordance with Formula 1 and Table 3.

the Wisłok River catchment (Fig. 1). The Quaternary porous aquifer is recharged mainly through rainfall infiltration [23]. Data obtained from the Institute of Meteorology and Water Management (Poland) show that in the years 1996-2016, the average annual rainfall was $690 \mathrm{~mm}$ in this area. The groundwater table is mostly unconfined. The confined head is observed only in the southern part of the research area, where loess and silts appear in the unsaturated zone weakly permeable loams [23]. Agricultural areas constitute $63 \%$ and forests $13 \%$ of the area [24].

\section{Method}

The groundwater pollution risk was determined qualitatively based on the approach applied by [1], among others, but in a significantly simplified manner. Two factors were assumed to be decisive, that is, potential impact of land use forms and the intrinsic vulnerability of groundwater to pollution (Fig. 2). Particular degrees of potential impact of land use forms on groundwater quality in this study were ranked from 1 to 3 , with the highest rating for the most adverse impact, that is, the most harmful one (Table 1). Vulnerability of groundwater to pollution was ranked as 1 to 4 , with the highest rating for the highest vulnerability grade. The classification of potential impacts of major forms of land use on groundwater quality assumed in this study is presented in Table 2.

The classification of the overall risk $(R)$ of groundwater pollution proposed by the authors has four grades: very high, high, moderate, and low (Table 3,
Fig. 2). The risk grade depends on the evaluation of the total rating obtained with the equation:

$$
R=L+V
$$

where $L$ is the rank of potential impact of land use forms on groundwater quality, $V$ is the rank of intrinsic vulnerability of groundwater to pollution, and ratings for both factors are evaluated on the basis of the assumed classification (Table 1).

The approach to the classification of the overall risk of groundwater pollution is that for areas with the same degree of intrinsic vulnerability of groundwater to pollution, the resultant overall risk of groundwater

Table 1. Factors accounted for in the groundwater pollution risk assessment (based on [1], simplified) and their classification; the grades of potential impact of land use forms and their ratings, and ratings of particular grades of vulnerability of groundwater to pollution adopted by the authors.

\begin{tabular}{|c|c|c|}
\hline Factor & Grade & Rating \\
\hline \multirow{2}{*}{$\begin{array}{c}\text { Potential impact } \\
\text { of land use forms } \\
(L)\end{array}$} & Adverse & 3 \\
\cline { 2 - 3 } & Potentially adverse & 2 \\
\cline { 2 - 3 } & No adverse impact & 1 \\
\hline \multirow{2}{*}{$\begin{array}{c}\text { Vulnerability } \\
\text { of groundwater } \\
\text { to pollution } \\
(V)\end{array}$} & Very high & 4 \\
\cline { 2 - 3 } & High & 3 \\
\cline { 2 - 3 } & Moderate & 2 \\
\hline
\end{tabular}


Table 2. Classification of potential impact of land use forms on groundwater quality (the authors' own elaboration).

\begin{tabular}{|c|c|c|}
\hline Impact & Characteristics of impact & Land use form \\
\hline Adverse & $\begin{array}{c}\text { Areal and diffused, long-lasting real or potential } \\
\text { sources of groundwater contamination }\end{array}$ & $\begin{array}{c}\text { Urban, industrial and trade areas } \\
\text { Arable lands } \\
\text { Areas occupied mainly by agriculture with participa- } \\
\text { tion of natural vegetation }\end{array}$ \\
\hline Potentially adverse & $\begin{array}{c}\text { Point, diffused or linear sources of } \\
\text { contamination, potential hazard for groundwater } \\
\text { quality }\end{array}$ & $\begin{array}{c}\text { Road and railway transport areas } \\
\text { Orchards and plantations } \\
\text { Areas of opencast mineral extraction }\end{array}$ \\
\hline No adverse impact & $\begin{array}{c}\text { Potential hazard negligible from a long-term } \\
\text { perspective }\end{array}$ & $\begin{array}{c}\text { Forests and bushes } \\
\text { Meadows and pastures }\end{array}$ \\
\hline
\end{tabular}

pollution will be higher where the degree (and rating) of the adverse impact of land use forms on groundwater quality is higher (Table 3). The spatial variability of groundwater pollution risk is determined in geographic information system (GIS) by overlaying the map of potential impacts of land use on the map of intrinsic vulnerability of groundwater to pollution (Fig. 2). The summation indicated by Formula (1) is implemented by overlapping layers with spatial distributions of both factors and then summing up the scores within the boundaries of individual polygons resulting from the intersection of the boundaries of sub-areas with individual ratings.

In the proposed approach to groundwater pollution risk assessment, the method adopted for the assessment of the intrinsic vulnerability of groundwater to pollution (factor $V$ ) was not modified. The potential impact of land use forms (factor $L$ ) that may lead to deterioration of groundwater quality in the analysed area is a reflection of the spatial and temporal nature of the harmful pressure of land use forms (Table 2).
The harmful pressure of land use results only from the form, type and amount of the mass load of chemical compounds, which for various reasons can potentially migrate from the ground surface to the groundwater. In factor $L$, therefore, no other parameters are taken into account, such as the recharge from effective infiltration of rainfall, which is dependent on the land cover, for example.

The analyses were based on the land use source data acquired from the Corine Land Cover system [24]. The land coverage specified for the analysed study area was reclassified with GIS to adjust the land use forms to the assumed classification. In the risk assessment of groundwater pollution, point contamination sources were omitted, as they are significant only on a local scale, while the vulnerability of groundwater to pollution is evaluated on supra-local or regional scale, in general.

To perform the assessment of the intrinsic vulnerability of groundwater to pollution in the study area, the DRASTIC method was applied [25]. Its original version adopts seven factors: depth to the

Table 3. Classification of the groundwater pollution risk (the authors' own elaboration); ratings of the vulnerability of groundwater to pollution $(\mathrm{V})$ and the potential impact of land use forms (L) according to Table 1; classification of potential impact of land use forms on groundwater quality according to Table 2; (n): rating.

\begin{tabular}{|c|c|c|}
\hline Risk & Characteristic & Rating \\
\hline Very high & $\begin{array}{c}\text { Areas of very high intrinsic vulnerability of groundwater to pollution (4) where land use forms with } \\
\text { adverse impacts on groundwater quality are located (3) }\end{array}$ & 7 \\
\hline \multirow{2}{*}{ High } & $\begin{array}{l}\text { Areas of high intrinsic vulnerability of groundwater to pollution (3) where land use forms with ad- } \\
\text { verse impacts on groundwater quality are located (3) }\end{array}$ & \multirow{2}{*}{6} \\
\hline & $\begin{array}{l}\text { Areas of very high intrinsic vulnerability of groundwater to pollution (4) where land use forms with } \\
\text { potentially adverse impacts on groundwater quality are located (2) }\end{array}$ & \\
\hline \multirow{3}{*}{ Moderate } & $\begin{array}{c}\text { Areas of moderate or low intrinsic vulnerability of groundwater to pollution ( } 2 \text { or } 1) \text { where land use } \\
\text { forms with adverse impacts on groundwater quality are located (3) }\end{array}$ & \multirow{3}{*}{$4-5$} \\
\hline & $\begin{array}{l}\text { Areas of high or moderate intrinsic vulnerability of groundwater to pollution ( } 3 \text { or } 2) \text { where land use } \\
\text { forms with potentially adverse impacts on groundwater quality are located (2) }\end{array}$ & \\
\hline & $\begin{array}{l}\text { Areas of very high or high intrinsic vulnerability of groundwater to pollution ( } 4 \text { or } 3) \text { where there is a } \\
\text { lack of land use forms with adverse impacts on groundwater quality (1) }\end{array}$ & \\
\hline \multirow{2}{*}{ Low } & $\begin{array}{l}\text { Areas of low intrinsic vulnerability of groundwater to pollution (1) where land use forms with poten- } \\
\text { tially adverse impacts on groundwater quality are located (2) }\end{array}$ & \multirow{2}{*}{$2-3$} \\
\hline & $\begin{array}{l}\text { Areas of moderate or low intrinsic vulnerability of groundwater to pollution ( } 2 \text { or } 1) \text { where there is a } \\
\text { lack of land use forms with adverse impacts on groundwater quality (1) }\end{array}$ & \\
\hline
\end{tabular}


groundwater table (weight 5); net recharge, that is, effective precipitation infiltration (4); aquifer media (3); type of soil (2); terrain surface topography (1); impact of lithology of unsaturated zone (5); and hydraulic conductivity of soil or rock in aquifer (3). The ratings of particular factors are from 1 to 10 , so after multiplication by their weights the full range of the
DRASTIC index is 23-226 [25]. A short presentation of this method is given by [26], among others. In the presented study, DRASTIC was used as the method of assessment of vulnerability of groundwater to pollution on the basis of analysis of comparative test results of various methods carried out by [17, 27-29]. The method operates with seven factors along with their

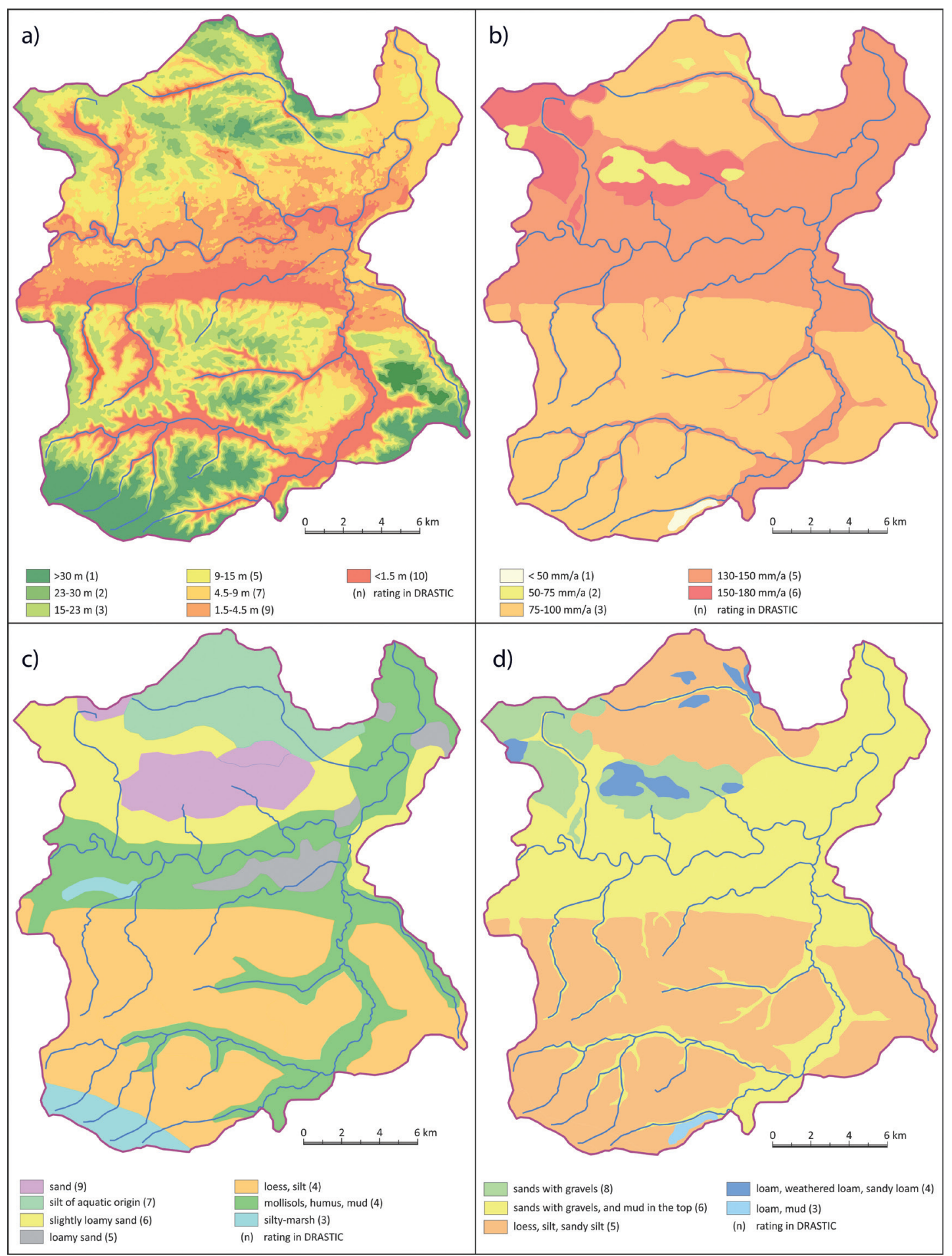

Fig. 3. Spatial variability of selected factors affecting vulnerability of groundwater to pollution: a) depth to groundwater table (data source: [23] and digital terrain model from srtm.csi.cgiar.org), b) recharge rate, c) topsoil (data source: map of soils in Poland at scale 1:300 000 by the Polish Geological Institute), d) lithology of unsaturated zone (data source: the Geological Map of Poland at scale 1:50 000 by the Polish Geological Institute). 
detailed division, allowing for the proper selection of the rating [25]. It makes it possible to properly model the hydrogeological conditions that characterize, in particular, the porous medium - as in the study area. This method is still frequently applied to the assessment of vulnerability of groundwater to pollution; for example, it was used in [3, 11, 26, 30-33], and others.

The authors of the DRASTIC method did not give the relationship between the index ranges and the appropriate degrees of intrinsic vulnerability of groundwater to pollution. Therefore, in this research, the author's own ranges of the DRASTIC index were adopted and are referred to the four degrees of vulnerability of groundwater to pollution accepted by the authors. A linear, four-grade partition of the full range of the DRASTIC index values was assumed and referred to the classification of the intrinsic vulnerability of groundwater to pollution: index values of 23-75 refer to low or very low vulnerability; 76-125 to moderate vulnerability; $126-175$ to high vulnerability; and 176-226 to very high vulnerability.

The spatial variability of four selected factors of the seven affecting vulnerability of groundwater to pollution in the study area accounted for in the DRASTIC method is presented in Fig. 3. The purpose of this selection was to focus on presenting only those results of the study related to the most important factors. There are maps of the four selected factors that were considered to have the greatest influence on groundwater vulnerability, that is, depth to the groundwater table, the lithology of the unsaturated zone, net recharge, and type of topsoil. The presentation and analysis of the influence of terrain surface topography on the vulnerability of groundwater to pollution was omitted in this paper because the weight of this factor is the smallest.

In Fig. 3 and in the discussion of the results of this study, two DRASTIC factors regarding the natural properties of the aquifer, that is, the lithology and the hydraulic conductivity of soil or rock of the aquifer, are also omitted. Neither of these factors affect the time, velocity, or load of contaminant transported downward from the terrain surface to shallow groundwater through the unsaturated zone. These factors affect the velocity at which a contamination plume will spread in the aquifer. In other words, they affect the volume and extent of the contamination plume in the aquifer, which will occur a certain time after reaching the groundwater and migrating in the direction of the water flow. Considering that the described research concerns groundwater pollution risk assessment based on vulnerability of groundwater to pollution and potential impact of land use forms, it was accepted that both of these factors are of secondary importance and may be omitted from the graphic presentation and analysis in this paper.

Effective infiltration of precipitation, that is, groundwater net recharge, means the part of the rainfall that percolates to the saturation zone, as indicated by [34], among others. An overview of recharge evaluation
Table 4. Effective infiltration coefficients of soil assumed for recharge rate estimation.

\begin{tabular}{|c|c|}
\hline Soil & $\begin{array}{c}\text { Effective infiltration } \\
\text { coefficient [\%] }\end{array}$ \\
\hline Sand and gravel & 25 \\
\hline Sand, gravel and loam & 22 \\
\hline Sand, gravel and mud & 20 \\
\hline Loess, sandy loess and silt & 14 \\
\hline Loam & 10 \\
\hline Clay & 5 \\
\hline
\end{tabular}

methods is given, for example by [34, 35]. One of many methods giving a spatially variable result is the Wet Spass water balance model [36]. Factors conditioning the recharge of shallow groundwater in selected catchments using the Wet Spass model with a spatially distributed parameter were identified by [35], among others. Their study revealed, inter alia, that changes in relationships between components of water balance having similar distributions are caused by differences in the type of land usage. However, due to a lack of some of the source data needed for the Wet Spass model, in the study described herein the recharge was estimated with a simplified method, that is, the infiltration method. The infiltration method is based on the assumption that the recharge is mainly influenced by the rainfall rate and lithology of topsoil, as indicated by [37-39], for example. Thus the estimated recharge is a derivative of the precipitation rate and effective infiltration coefficients of the soil (Table 4). The data sources were a geological map of Poland at a scale of 1:50 000 from the Polish Geological Institute and data from the Institute of Meteorology and Water Management (Poland).

The analysis of the spatial relationships between the obtained result of the overall risk of groundwater pollution assessment and the main factors taken into account in this risk assessment was carried out on the basis of a graphical comparison between the spatial coverage of areas characterized by the particular resultant degrees of groundwater pollution risk and areas with particular ratings of these main factors.

\section{Results and Discussion}

The spatial variability of land use in the study area and the potential impact of land use on groundwater pollution risk determined in accordance with the authors' own adopted classification and rating (Tables 1 and 2) are presented in Fig 4a) and 4b), respectively. The spatial variability of the vulnerability of groundwater to pollution determined in accordance with the authors' own adopted classification of the full range of the DRASTIC index calculated on the basis of all seven 
factors is presented in Fig. 4c). The spatial variability of groundwater pollution risk determined in accordance with Formula (1) and the author's own adopted classification of groundwater pollution risk (Table 3 ) is presented in Fig. 4d).

The correlation analysis of the spatial distribution of the four selected factors affecting the intrinsic vulnerability of the groundwater presented in Fig. 3 with the spatial variability of the vulnerability of groundwater to pollution (Fig. 4c) confirmed some dependencies described in the literature on the subject. High groundwater vulnerability was observed in areas where groundwater was shallow (Fig. 3a). The shallower the groundwater, the shorter the migration time of the pollutant mass, during which its natural attenuation may occur through biodegradation, chemical

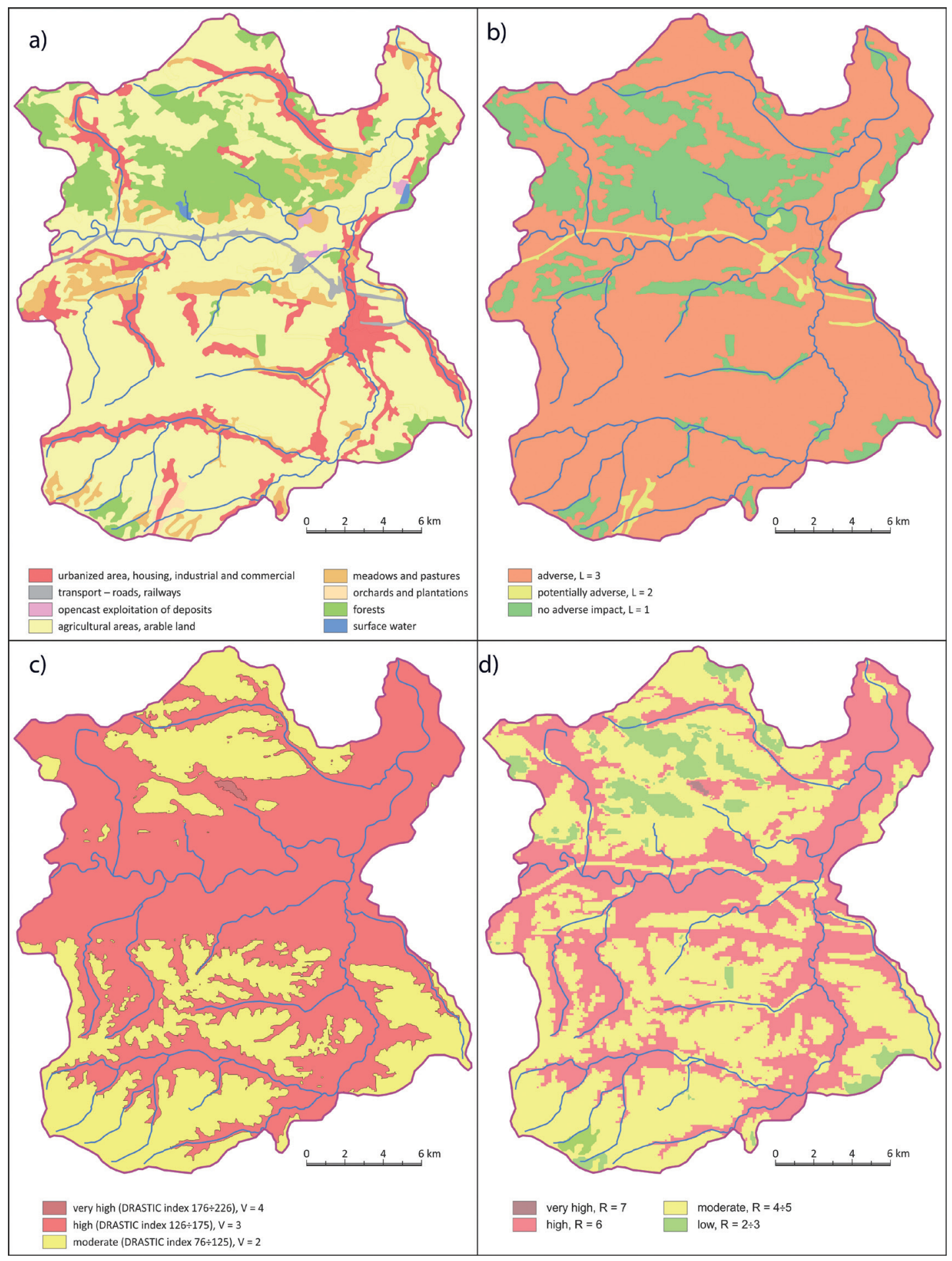

Fig. 4. Spatial variability of land use in the study area (data source: [24]) - a), and factors affecting the groundwater pollution risk: potential impact of land use $-\mathrm{b}$ ), vulnerability of groundwater to pollution $-\mathrm{c}$ ), and spatial variability of groundwater pollution risk $-\mathrm{d}$ ). Ratings of $\mathrm{L}$ and $\mathrm{V}$ factors in accordance with Table 1 and Fig. 2; rating of risk (R) in accordance with Formula 1 and Table 3. 
decomposition, and/or adsorption, as indicated for example by [1, 25, 40-42].

A belt of terrain in the east-west direction with an average annual recharge rate of over $130 \mathrm{~mm}$ can be found in the spatial distribution of this factor (Fig. 3b). This zone coincides with the well-permeable topsoil, which is mostly sandy (Fig. 3c), and with sands and gravels in the unsaturated zone (Fig. 3d). This causes the vulnerability of groundwater to pollution in this part of the study area to be very high (Fig. 4c). Comparison of these three maps confirmed that the dependence of the influence of the topsoil type is less than that of the type of lithology of the unsaturated zone, which is indicated by the differences between their weights (2 and 5, respectively) in the DRASTIC method. A comparison of the groundwater pollution risk

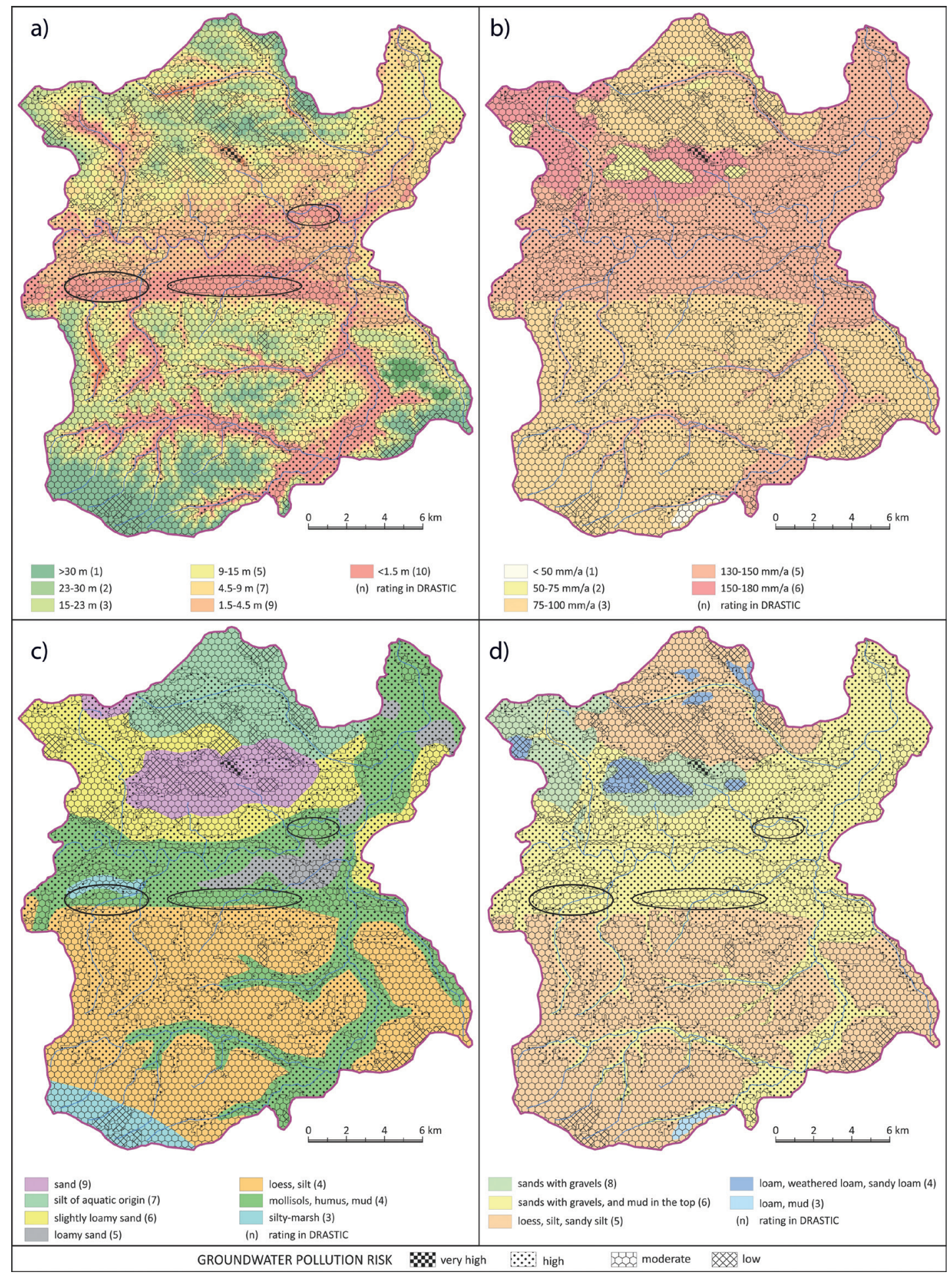

Fig. 5. Spatial relationship between selected factors affecting the groundwater pollution risk and the assessed risk grade: a) depth to groundwater, b) recharge rate, c) topsoil, d) lithology of unsaturated zone. Black envelopes - explanation in the text. 
map (Fig. 4d) with the map of intrinsic vulnerability of groundwater to pollution (Fig. 4c) confirms that areas with high and moderate groundwater pollution risk are usually characterized by high and moderate vulnerability to pollution, respectively. It is also apparent that this general dependence in some sub-areas overlaps with the potential impact of land use. This can be seen in the northern part of the study area and in several small sub-areas near the southern border, where the assessment of the groundwater pollution risk indicates that these sub-areas are at low risk but their vulnerability of groundwater to pollution is moderate.

Agricultural and urban terrains dominate the study area (Fig. 4a). As a result, the assumed classification of potential impact of land use on groundwater quality (Table 2) shows the dominance of adverse influences (Fig. 4b). The next consequence of this fact, combined with the fact that high vulnerability of groundwater to pollution prevails in the study area, is that high groundwater pollution risk also prevails. The obtained map of this risk shows that $0.3 \%$ of the study area is characterized by very high risk, $50 \%$ by high risk, $45 \%$ by moderate risk, and $4.7 \%$ by low risk (Fig. $4 d$ ).

The spatial relationships between the obtained result of the groundwater pollution risk assessment and the main factors taken into account in this risk assessment are presented in Figs 5 and 6. In areas where the groundwater table is shallow, the groundwater pollution risk is usually high or very high (Fig. 5a). In areas where the mean annual effective infiltration does not exceed $75 \mathrm{~mm}$, this risk is low or moderate, whereas when it is over $130 \mathrm{~mm}$, the risk is high (Fig. 5b). The presence of low-permeability soils, for example, silt, loess, or loam, slows down the downward migration of pollutants, thus lowering the groundwater pollution risk (Fig. 5d). The analysis of these spatial relationships confirmed that the depth to the groundwater table, the recharge rate, and the lithology of soils in the unsaturated zone are important factors influencing the groundwater pollution risk. It was also confirmed that the effect of the topsoil type is much less visible (Fig. 5c) than the impact of the unsaturated zone lithology, which results from the difference between their weights in DRASTIC.

The study also confirmed that the groundwater pollution risk is considerably conditioned by the potential impact of land use forms (Fig. 6). The biggest risk in the study area was created by agriculture, as arable lands constitute over $60 \%$ of the area (Fig. 3a). Arable land is qualified as a land use form characterized by a potentially adverse impact on groundwater quality (Table 2).

However, in some sub-areas of the study area, the spatial relationship between the obtained result of the assessment of overall risk of groundwater pollution and the main factors taken into account in this risk assessment is ambiguous. The sum of mutual interactions of values and weights of factors affecting the groundwater pollution risk is a result of the accumulative or compens ative effect of these factors' values and weights. For the particular factors, some rating values increase the evaluated groundwater pollution risk, while others lower it. In the study area, the compensation effect of some factors' ratings and weight values is most visible in the case of spatial relationships between the depth to the groundwater table and the groundwater pollution risk (Fig. 5a). In the central part of the area, there are three zones (indicated in this figure by black envelopes) where, despite the shallow groundwater, with a depth to groundwater of less than $1.5 \mathrm{~m}$ (DRASTIC rating 10, weight 5), there is merely a moderate groundwater pollution risk. In these three zones, a similar effect of compensating the values of ratings of some parameters is also visible in the case of the lithology of the unsaturated zone where permeable sands with gravels occur (rating 6 , weight 5 ) and the pollution risk is only moderate (Fig. $5 \mathrm{~d}$ ). One of the reasons for the lower groundwater pollution risk in the indicated zones is the occurrence of semipermeable topsoils such as mollisols, humus and mud (rating 4, weight 2) (Fig. 5c). However, the main cause is the occurrence of areas of meadows and pastures, where no adverse impact of land use occurs, so there is a rating of 1 for this criterion in the assumed groundwater pollution risk assessment (Fig. 6 and 4a, 4b).

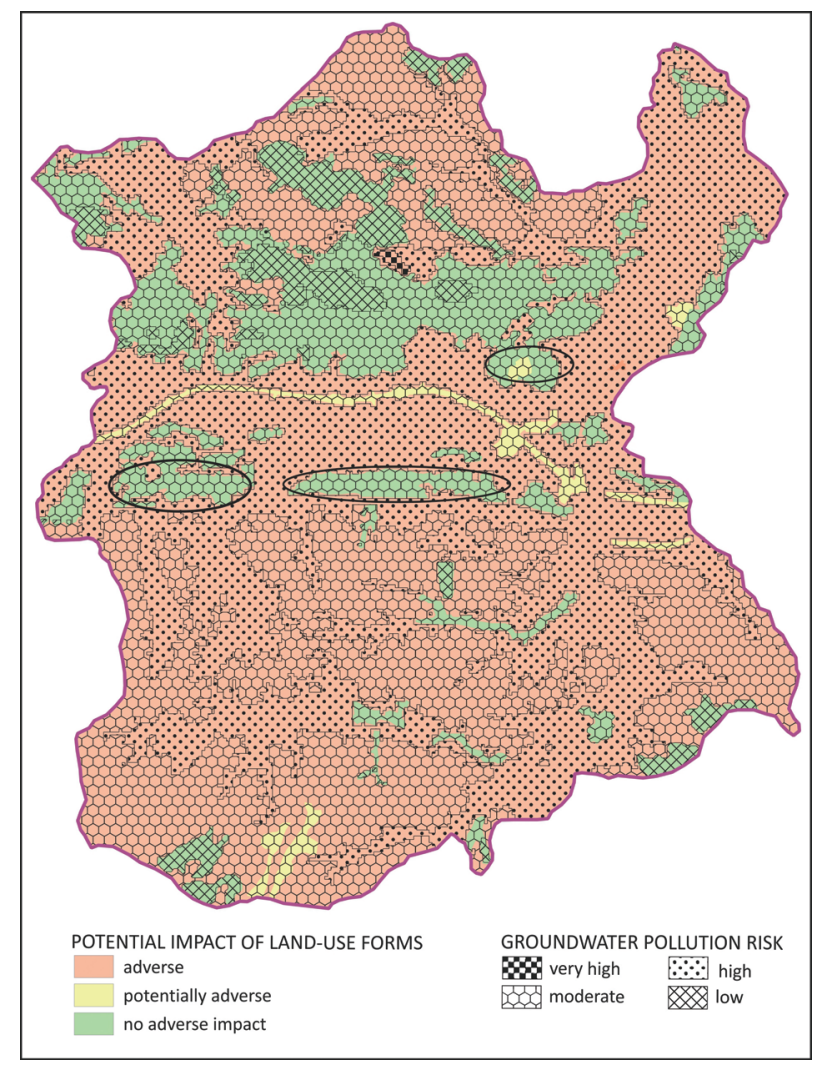

Fig. 6. Spatial relationship between potential impact of land use forms and the assessed groundwater pollution risk grade. Black envelopes - explanation in the text. 
Moreover, the effects the above-mentioned conditions may be partly blurred by the broad range of the DRASTIC index that is 50 scores, assumed in the classification for the four particular assumed grades of vulnerability of groundwater to pollution. However, increasing the number of degrees of vulnerability of groundwater to pollution by one will not lead to a large change: the range for a single degree will be 40 scores, which is also a wide range. Increasing the number of degrees by a larger amount also does not seem to be a good solution because it will be very difficult to clearly define how the adjacent degrees of vulnerability to pollution will differ from each other.

Despite the indicated uncertainties, the obtained result of the assessment of the overall risk of groundwater pollution in the study area was not validated by comparing this risk - at a potential character, with the currently observed empirical results of groundwater quality. The question of such validation seems be complicated and ambiguous, so there does not seem to be an obvious need for it as part of this study because it may lead to a partly false solution.

Validation usually consists in a comparative analysis to determine whether the current groundwater quality is worse everywhere in areas with a high degree of groundwater pollution risk than in areas with low pollution risk. In order to reduce any non-compliance in this comparison, it is possible (i) to fit the originally accepted ranges and/or weights of individual factors of the DRASTIC index (that is, the universal index, designed for use under any condition) to particular grades of vulnerability of groundwater to pollution and (ii) to change the number of groundwater intrinsic vulnerability grades and/or the grades of overall risk of groundwater pollution.

However, by accepting nitrates as an indicator of groundwater pollution, validation and assessment of the groundwater specific vulnerability to pollution by nitrates (only) will be performed instead of an assessment of the intrinsic vulnerability resulting purely from hydrogeological conditions. As a consequence, validation and assessment of the specific risk of groundwater pollution by nitrates (only) will be realized instead of an assessment of the overall risk of groundwater pollution by any chemical compound originating from any source.

It seems obvious that in areas with a high degree of overall and specific risk of groundwater pollution, the current groundwater quality everywhere must be worse than in areas where the pollution risk is low. This means, for example, that currently observed nitrate concentrations must be higher everywhere in areas with a high degree of overall and specific risk of groundwater pollution than in areas with low risk of pollution. If nitrate concentrations are not higher at present, then the groundwater pollution risk should be fitted accordingly by reducing it, usually by changing the factors and their weights and/or ratings.
The partial inadequacy of the indicated expectation is due to the fact that it does not take into account the possibility that fertilizer is applied on arable fields, but the total doses of mineral and organic fertilizer used do not exceed the thresholds for particular types of crops so far. This means that the whole fertilizer dose is consumed by cultivation so far and consequently nitrates do not migrate below the topsoil profile. As a result, the current groundwater quality in this area is still good, but this is not equivalent to the assumption that the overall risk of groundwater pollution in this area is and will be low. The risk of potential pollution is high because the fertilizer doses can be significantly increased at any time.

On the other hand, validation may consist in a comparative analysis to determine whether current groundwater quality is better everywhere in areas with low groundwater pollution risk than in areas with high pollution risk. If, in an area with low groundwater pollution risk, observed concentrations of the selected indicator of water quality are not lower than those in areas with a higher degree of risk, then the degree of groundwater pollution risk should be adjusted accordingly by increasing it. It seems obvious that the current groundwater quality must be better everywhere in areas with a low degree of the groundwater pollution risk than in areas where the pollution risk is high.

The partial inadequacy of the indicated expectation is due to the fact that it does not take into account the example scenario. In this scenario, the observation point of the groundwater quality is located in the forest but close to its border in an aquifer covered with loam, which isolates it from the surface, and the risk of groundwater pollution at this point as a result of anthropopressure is close to zero. The neighbouring part of the same aquifer is not isolated from the land surface, where very intensive, long-term fertilization occurs on light, sandy soil. The direction of groundwater flow with nitrates is from the area of agricultural crops to the forest. Consequently the measured concentration of nitrates at the monitoring point is similar to the concentration observed under the fertilized land. As a result, the groundwater quality at this point is permanently poor, but this is not equivalent to the assumption that the groundwater pollution risk in the entire forest area under the loam is high.

It seems, therefore, that the subject of the validation methods and the criteria of research results similar to those presented in this paper are ambiguous and still require a separate in-depth and multifaceted analysis.

To obtain a more precise risk assessment of groundwater pollution that would be better fitted to the specific character of land use, attempts should be made to work out a quantitative method of performing this risk evaluation. This method should merge the quantitative evaluation of the potential impact of land use forms with quantitative assessment of the intrinsic vulnerability of 
groundwater to pollution. The quantitative estimation of the impact of industrial land use should be based on a risk analysis of accidents at industrial facilities, leakage from urban sewers and waste disposal sites, and the like. The risk of agricultural impact, that is, mainly fertilizer application, should be evaluated by the method of balancing the predicted nitrogen load contained in the predicted total doses of mineral and organic fertilizers with the nitrogen demand of particular types of agricultural crops grown on a given topsoil type. The intrinsic vulnerability of groundwater should be quantitatively assessed using a method based on the mean residence time (mean travel time) of conservative pollutants in the unsaturated zone, as already applied by [40-44], for example.

\section{Conclusions}

The study confirmed that particular degrees of groundwater pollution risk and their spatial variabilities are a result of the interaction of values and weights of major factors affecting the vulnerability of groundwater to pollution that are taken into account and additional interaction with the potential impact of land use.

The assumed method of qualitative assessment of groundwater pollution risk, which employed the intrinsic vulnerability of groundwater to pollution and the potential impact of land use forms, together with the proposed classification of groundwater pollution risk, made it possible to determine areas of high risk of groundwater pollution in the study area in an effective manner. The assumed classification of the potential impact of major forms of land use on groundwater quality may be further extended as part of future research by considering a more extensive set of sources of groundwater pollution.

Presentation of the spatial relationships between selected factors affecting the groundwater pollution risk and the assessed degree of this risk in a graphical manner allows for a better understanding and more thorough analysis of the reasons why the resultant spatial distribution of this risk was obtained.

The map of groundwater pollution risk based on the proposed method and classification of groundwater pollution risk could help with land use management on a local scale, leading to targeted measures to protect groundwater quality, for example by limiting fertilizer doses in agricultural areas.

\section{Acknowledgements}

This research was financially supported by the AGH University of Science and Technology (grant No. 11.11.140.797). The authors wish to thank all those involved in the review of this paper for their valuable remarks, which significantly improved the value of this article.

\section{Conflict of Interest}

The authors declare no conflict of interest.

\section{References}

1. ZWAHLEN F. COST 620 - Vulnerability and risk mapping for the protection of carbonate (karst) aquifers - Final report. Office for Official Publications of the European Communities, Luxembourg, European Communities, 2004.

2. MIMI Z.A., ASSI A., Intrinsic vulnerability, hazard and risk mapping for karst aquifers: A case study. Journal of Hydrology, 364 (3-4), 298, 2009.

3. SAIDI S., BOURI S., BEN DHIA H. Groundwater vulnerability and risk mapping of the Hajeb-jelma aquifer (Central Tunisia) using a GIS-based DRASTIC model. Environmental Earth Sciences, 59 (7), 1579, 2010.

4. KAZAKIS N., OIKONOMIDIS D., VOUDOURIS K.S. Groundwater vulnerability and pollution risk assessment with disparate models in karstic, porous, and fissured rock aquifers using remote sensing techniques and GIS in Anthemountas basin, Greece. Environmental Earth Sciences, 74 (7), 6199, 2015.

5. ENTEZARI M., YAMANI M., AGHDAM M.J. Evaluation of intrinsic vulnerability, hazard and risk mapping for karst aquifers, Khorein aquifer, Kermanshah province: a case study. Environmental Earth Sciences, 75 (5), 435, 2016.

6. JAFARI F., JAVADI S., GOLMOHAMMADI G., MOHAMMADI K., KHODADADI A., MOHAMMADZADEH M. Groundwater risk mapping prediction using mathematical modeling and the Monte Carlo technique. Environmental Earth Sciences, 75 (6), 491, 2016.

7. VAN DER GUN J. Data, information, knowledge and diagnostics on groundwater. In: Advances in Groundwater Governance, Villholth K.G., Lopez-Gunn E., Conti K., Garrido A., van der Gun J., Eds., CRC Press, Taylor \& Francis Group, London, 193, 2017.

8. WIEGANT D.A., VAN STEENBERGEN F. Steps towards groundwater-sensitive land use governance and management practices. In: Advances in Groundwater Governance, Villholth K.G., Lopez-Gunn E., Conti K., Garrido A., van der Gun J., Eds., CRC Press, Taylor \& Francis Group, London, 307, 2017.

9. OSTROM L.T., WILHELMSEN C.A. Risk assessment tools, techniques, and their applications. Wiley, New Jersey, 2012.

10. BAALOUSHA H.M. Vulnerability, probability and groundwater contamination risk. Environmental Earth Sciences, 76 (11), 383, 2017.

11. SAIDI S., BOURI S., BEN DHIA H., ANSELME B. Assessment of groundwater risk using intrinsic vulnerability and hazard mapping: application to Souassi aquifer, Tunisian Sahel. Agricultural Water Management, 98 (10), 1671, 2011.

12. WANG J., HE J., CHEN H. Assessment of groundwater contamination risk using hazard quantification, a modified DRASTIC model and groundwater value, Beijing Plain, China. Science of the Total Environment, 432, 216, 2012.

13. KAZAKIS N., VOUDOURIS K.S. Groundwater vulnerability and pollution risk assessment of porous 
aquifers to nitrate: Modifying the DRASTIC method using quantitative parameters. Journal of Hydrology, 525, 13, 2015.

14. HUAN H., WANG J., ZHAI Y., XI B., LI J., LI M. Quantitative evaluation of specific vulnerability to nitrate for groundwater resource protection based on processbased simulation model. Science of the Total Environment, 550, 768, 2016.

15. SADAT-NOORI M., EBRAHIMI K. Groundwater vulnerability assessment in agricultural areas using a modified DRASTIC model. Environmental Monitoring and Assessment, 188 (1), 19, 2016.

16. HE H., LI X.-G., LI X., CUI J., ZHANG W., XU W. Optimizing the DRASTIC method for nitrate pollution in groundwater vulnerability assessments: a case study in China. Polish Journal of Environmental Studies, 27 (1), 95, 2018.

17. KHOSRAVI K., SARTAJ M., TSAI F.T.-C., SINGH V.P., KAZAKIS N., MELESSE A.M., PRAKASH I., BUI D.T., PHAM B.T. A comparison study of DRASTIC methods with various objective methods for groundwater vulnerability assessment. Science of the Total Environment, 642, 1032, 2018.

18. NOORI R., GHAHREMANZADEH H., KLØVE B., ADAMOWSKI J.F., BAGHVAND A. Modified-DRASTIC, modified-SINTACS and SI methods for groundwater vulnerability assessment in the southern Tehran aquifer. Journal of Environmental Science and Health, Part A, 30, $1,2018$.

19. KOZŁOWSKI M., SOJKA M. Applying a modified DRASTIC model to assess groundwater vulnerability to pollution: a case study in central Poland. Polish Journal of Environmental Studies, 28 (3), 1, 2019.

20. DĄBROWSKA D., WITKOWSKI A.J., SOŁTYSIAK M. Application of pollution indices for the spatiotemporal assessment of negative impact of a municipal landfill on groundwater (Tychy, southern Poland). Geological Quarterly, 62 (3), 496, 2018.

21. SOŁTYSIAK M., DĄBROWSKA D., JAŁOWIECKI K., NOURANI V.A multi-method approach to groundwater risk assessment: a case study of a landfill in southern Poland. Geological Quarterly, 62 (2), 361, 2018.

22. LI R., MERCHANT J.W. Modeling vulnerability of groundwater to pollution under future scenarios of climate change and biofuels-related land use change: A case study in North Dakota, USA. Science of the Total Environment, 447, 32, 2013.

23. BADACZ G., BIELEC B., OPERACZ T. Hydrogeological Map of Poland 1:50000 - main useful aquifer. Sheets: Leżajsk (956), Sieniawa (957), Przeworsk (983), Jarosław (984). Polish Geological Institute, Warszawa, 1998 [in Polish].

24. CLC. Corine Land Cover. Chief Inspectorate of Environmental Protection. 2012. Available online: http:// clc.gios.gov.pl (Accessed on 31.05.2017).

25. ALLER L., BENNETT T., LEHR J.H., PETTY R.J., HACKETT G. DRASTIC: a standardized system for evaluating ground water pollution potential using hydrogeologic settings. USGS, Ada, Oklahoma. 1987.

26. SHIRAZI S.M., IMRAN H.M., AKIB S., YUSOP Z., HARUN Z.B. Groundwater vulnerability assessment in the Melaka State of Malaysia using DRASTIC and GIS techniques. Environmental Earth Sciences, 70 (5), 2293, 2013.

27. BRINDHA K., ELANGO L. Cross comparison of five popular groundwater pollution vulnerability index approaches. Journal of Hydrology, 524, 597, 2015.

28. KUMAR P., BANSODB.K.S., DEBNATHS.K., THAKUR P.K., GHANSHYAM C. Index-based groundwater vulnerability mapping models using hydrogeological settings: a critical evaluation. Environmental Impact Assessment Review, 51, 38, 2015.

29. HERMANOWSKI P., IGNASZAK T. Groundwater vulnerability based on four different assessment methods and their quantitative comparison in a typical North European Lowland river catchment (the Pliszka River catchment, western Poland). Geological Quarterly, 61 (1), 166, 2017.

30. YU C., ZHANG B.X., YAO Y.Y., MENG F.H., ZHENG C.M. A field demonstration of the entropy-weighted fuzzy DRASTIC method for groundwater vulnerability assessment. Hydrological Sciences Journal, 57 (7), 1420, 2012.

31. KHEMIRI S., KHNISSI A., BEN ALAYA M., SAIDI S., ZARGOUNI F. Using GIS for the comparison of intrinsic parametric methods assessment of groundwater vulnerability to pollution in scenarios of semi arid climate. The case of Foussana groundwater in the central of Tunisia. Journal of Water Resource and Protection, 5 (8), 835, 2013.

32. BONFANTI M., DUCCI D., MASETTI M., SELLERINO M., STEVENAZZI S. Using statistical analyses for improving rating methods for groundwater vulnerability in contamination maps. Environmental Earth Sciences, 75 (12), 1003, 2016.

33. KROGULEC E., TRZECIAK J. DRASTIC assessment of groundwater vulnerability to pollution in the Vistula floodplain in central Poland. Hydrology Research, 48 (4), 1088, 2016.

34. SCANLON B.R., HEALY R.W., COOK P.G. Choosing appropriate techniques for quantifying groundwater recharge. Hydrogeology Journal, 10, 18, 2002.

35. GRAF R., PRZYBYŁEK J. Application of the WetSpass simulation model for determining conditions governing the recharge of shallow groundwater in the Poznan Upland, Poland. Geologos, 24 (3), 189, 2018

36. BATELAAN O., DE SMEDT F. WetSpass: a flexible, GIS based, distributed recharge methodology for regional groundwater modelling. In: Gehrels H., Peters J., Hoehn E., Jensen K., Leibundgut C., Griffioen J., Webb B., Zaadnoordijk W.J., Eds., Impact of Human Activity on Groundwater Dynamics. International Association of Hydrological Science Publications, 269, 11, IAHS Press, 2001.

37. STAŚKO S., TARKA R., OLICHWER T. Groundwater recharge evaluation based on the infiltration method. In: Groundwater Quality Sustainability, Maloszewski P., Witczak S., Malina G., Eds., International Association of Hydrogeologists, Selected Papers, 17, 189, 2012.

38. TARKA R., OLICHWER T., STAŚKO S. Evaluation of groundwater recharge in Poland using the infiltration coefficient method. Geological Quarterly, 61 (2), 384, 2017.

39. GUMUŁA-KAWĘCKA A., SZYMKIEWICZ A., JAWORSKA-SZULC B., PRUSZKOWSKA-CACERES M., GORCZEWSKA-LANGNER W. Preliminary estimation of groundwater recharge on Brda river outwash plain. 10 ${ }^{\text {th }}$ Conference EKO-DOK 2018, E3S Web of Conferences, 44, 00050, 2018.

40. VOIGT H.J., HEINKELE T., JAHNKE C., WOLTER R. Characterisation of groundwater vulnerability to fulfil requirements of the water framework directive of the European Union. GeofísicaInternacional, 43, 567, 2004. 
41. YU C., YAO Y., CAO G., ZHENG CH. A field demonstration of groundwater vulnerability assessment using transport modeling and groundwater age modeling, Beijing Plain, China. Environmental Earth Sciences, 73 (9), 5245, 2014.

42. WACHNIEW P., ZUREK A.J., STUMPP CH., GEMITZI A., GARGINI A., FILIPPINI M., ROZANSKI K., MEEKS J., KVÆRNER J., WITCZAK S. Towards operational methods for the assessment of intrinsic groundwater vulnerability: a review. Critical Reviews in Environmental Science and Technology, 46 (9), 827, 2016.
43. WITCZAK S., DUDA R., ŻUREK A. The Polish concept of groundwater vulnerability mapping. In: Groundwater Vulnerability Assessment and Mapping, Witkowski A.J., Kowalczyk A., Vrba J., Eds., International Association of Hydrogeologists, Selected Papers on Hydrogeology, 11, Taylor \& Francis, 45, 2007.

44. SZYMKIEWICZ A.

A., POTRYKUS D. PRUSZKOWSKA-CACERES M., GORCZEWSKALANGNER W. Estimation of conservative contaminant travel time through vadose zone based on transient and steady flow approaches. Water, 10 (10), 1417, 2018. 
